\title{
Interaction of cCMP with the $\mathrm{CGK}$, CAK and MAPK kinases in murine tissues
}

\author{
Stefanie Wolfertstetter ${ }^{1 *}$, Frank Schwede ${ }^{2}$, Franz Hofmann ${ }^{3}$, Jens Schlossmann ${ }^{1}$ \\ From 7th International Conference on cGMP Generators, Effectors and Therapeutic Implications \\ Trier, Germany. 19-21 June 2015
}

\begin{abstract}
Background
cAMP and cGMP are well established second messengers that are essential for numerous of (patho)physiological processes. These purine cyclic nucleotides activate cAK and cGK, respectively. So far, there was no evidence of further cyclic nucleotides acting as second messengers. Meanwhile the existence of cCMP was described $[1,2]$. cCMP activates the purified cyclic nucleotide-dependent protein kinases cAK and cGK and induces relaxation of vascular smooth muscle via cGKI [3]. Furthermore, it was postulated that cCMP is relevant for cell growth [4] and blood cell function [5]. However, functions regulated by cCMP are mostly unknown.
\end{abstract}

\section{Methods and results}

To elucidate propable functions cCMP-binding and -activated proteins were identified using different methods. Competitive binding assays identified cAK, cGKI, and cGKII as cCMP-binding proteins in murine tissue lysates, using 4-AH-cCMP agarose. cCMP $(200 \mu \mathrm{M})$ was added $(+)$ or omitted (-) during the affinity chromatography experiments to investigate the specificity of the binding. An interaction between $\mathrm{CCMP} / \mathrm{MAPK}$ and a protein-protein complex of MAPK/cGK were detected via cCMP affinity chromatography and co-immunoprecipitation, respectively. Interestingly, no specific interaction of MAPK with 8-AET-cGMP agarose was detected. Moreover, DB-cCMP $(100 \mu \mathrm{M})$ was also able to stimulate the phosphorylation of $\mathrm{p} 44 / \mathrm{p} 42$ MAPK. The phosphorylation of MAPK was inhibited by the addition of the PKA inhibitor $\mathrm{AS}_{5-24}$, suggesting a stimulatory function for PKA in CCMP-mediated MAPK phosphorylation. To elucidate the role of cGK in murine tissues in

\footnotetext{
* Correspondence: stefanie.wolfertstetter@chemie.uni-regensburg.de ${ }^{1}$ Department of Pharmacology and Toxicology, University of Regensburg, Germany

Full list of author information is available at the end of the article
}

this process, we used cGKII knockout (cGKII KO) and cGKI knockout (cGKI KO) mice. We detected stimulation in the jejunum tissues from cGKI KO and cGKII $\mathrm{KO}$ mice. It is interesting to note that the phosphorylation in the jejunum cGKII KO tissue was significantly increased when compared with the WT and cGKI KO tissues, suggesting an inhibitory role for cGKII in cCMP-induced MAPK phosphorylation in the jejunum.

\section{Conclusion}

These results suggest that MAPK signaling is regulated by cGMP-dependent protein kinases upon activation by cCMP. Hence, cCMP could potentially act as a second messenger in the cAK/cGK and MAPK signaling pathways and play an important role in physiological processes of the jejunum.

\section{Acknowledgments \\ This work was supported by the Bavarian state. \\ Authors' details \\ ${ }^{1}$ Department of Pharmacology and Toxicology, University of Regensburg, Germany. ${ }^{2}$ Biolog Life Science Institute, Bremen, Germany. ${ }^{3}$ Carvas, Institute for Pharmacology and Toxicology, TU Munich, Munich, Germany.}

Published: 2 September 2015

\section{References}

1. Newton RP, Salih SG, Salvage BJ, Kingston EE: Extraction, purification and identification of cytidine $3^{\prime}, 5^{\prime}$-cyclic monophosphate from rat tissues. Biochem J 1984, 221(3):665-673.

2. Bähre H, Hartwig C, Munder A, Wolter S, Stelzer T, Schirmer B, et al: CCMP and cUMP occur in vivo. Biochem Biophys Res Commun 2015, 460(4):909-914.

3. Desch M, Schinner E, Kees F, Hofmann F, Seifert R, Schlossmann: Cyclic cytidine 3',5'-monophosphate (cCMP) signals via cGMP kinase I. FEBS Lett 2010, 584(18):3979-3984.

4. Cheng YC, Bloch A: Demonstration, in leukemia L-1210 cells, of a phosphodiesterase acting on 3':5'-cyclic CMP but not on 3':5'-cyclic AMP or 3':5'-cyclic GMP. J Biol Chem 1978, 253(8):2522-2524.

5. Ervens J, Seifert R: Differential modulation by N4, 2'-O-dibutyryl cytidine $3^{\prime}: 5$ '-cyclic monophosphate of neutrophil activation. Biochem Biophys Res Commun 1991, 174(1):258-267. 
doi:10.1186/2050-6511-16-S1-A101

Cite this article as: Wolfertstetter et al:: Interaction of CCMP with the CGK, CAK and MAPK kinases in murine tissues. BMC Pharmacology and Toxicology 2015 16(Suppl 1):A101.

Submit your next manuscript to BioMed Central and take full advantage of:

- Convenient online submission

- Thorough peer review

- No space constraints or color figure charges

- Immediate publication on acceptance

- Inclusion in PubMed, CAS, Scopus and Google Scholar

- Research which is freely available for redistribution

Submit your manuscript at www.biomedcentral.com/submit 